\title{
A review of sustainable facilities management knowledge and practice
}

\author{
Timothy Kurannen Baaki ${ }^{1}$, , Mohamad Rizal Baharum ${ }^{1}$ and Azlan Shah Ali ${ }^{1}$ \\ ${ }^{1}$ Department of Building Surveying, Faculty of Built Environment, University of Malaya, 50603 Kuala Lumpur, Malaysia
}

\begin{abstract}
Sustainability is seen as a far-reaching issue now, and one which the facilities management [FM] profession cannot overlook. This paper explores current sustainable facilities management [SFM] knowledge and practice with specific focus on performance as part of a research focus toward proposing a sustainable FM performance management framework for sustainable healthcare waste management in Malaysia. This paper utilized a review of extant literature on the subject of SFM, FM performance and FM development in Malaysia as source of information. Findings reflect the increasing recognition of the need for the strategic FM function, and how facilities managers are best positioned to drive organizations' sustainability agendas. In Malaysian context, this recognition is barely evident as findings show FM practice is still immature and predominantly operational. Unlike developed FM markets, FM relevance in Malaysia is being driven by the public sector. Also findings show a disharmony between organizations' sustainability priority areas and the responsibilities for facilities managers to execute them where the sustainability policy of organizations prioritize one FM service and the facilities managers' responsibilities prioritize another. As most of SFM implementation is driven by legislation this seems to strengthen the position that, organizations continue to view support services as non-value-adding, as unavoidable liabilities. The implication of this is the pressure on the FM function to continually express its strategic relevance to organizations by tangible value-adding performance output. This creates a new perspective to measuring and managing facilities performance. This paper therefore elevates the importance of FM performance management in SFM context taking into account the peculiar position of the facilities manager. This is seen as a way forward for FM to better express its value to the organization
\end{abstract}

\section{Introduction}

Sustainability is seen as a far-reaching issue now, and one which the facilities management [FM] profession cannot overlook [1]. In a 2007 IFMA report, sustainability was identified as one of the key areas FM professionals need to develop their competencies in order to face the demands, challenges and opportunities of sustainable development and practices [2]. With the increasing relevance of FM toward business success, the FM function has transformed from just a cost cutting option to a strategic link between organization's core business and support services. Facilities management professionals are seen as being "at the forefront of organizational behavior change and in a position to influence individuals working in business; government departments and public services" [3] p. 59. The concept of sustainable facilities management [SFM] has gained relevance recently in an attempt to integrate FM functions with sustainability. The facilities management profession is presented with this need in two perspectives. One, because of the negative impact of existing buildings over the environment [4], and on the other hand, the increasing demand for technical knowledge required of facilities managers to understand the complexities of intelligent buildings and their operation $[3,5]$. Aspects such as reduction in energy consumption, productivity increases, waste reduction, etc. have been identified as tangible benefits capable of winning organizations' management commitment toward sustainability. It is noted that the facilities manager is in a unique position and is often seen as the leader of an organization's sustainability policy [6]. Elmualim et al. [3] opined that there is a pressing need for practical tools for sustainable facilities management as well as a need for the facilities manager championing the cause of sustainability within their organizations. Baharum \& Pitt [5] demonstrated the need for green FM intellectual capital in achieving overall sustainability and profitability for an organisation. The implication of this is the pressure on the FM function to continually express its strategic relevance to organizations by tangible value-adding performance output to support their organizations sustainability goals. Despite the ability to actively champion and implement activities capable of delivering sustainability benefits to organizations, this role is not fully recognized and appreciated [7]. This creates a new perspective to facilities performance measurement and management. Through the review of existing literature, this paper explores current sustainable facilities management [SFM] knowledge and practice with specific focus on performance, as part of a research toward proposing a sustainable FM performance management framework for 
Table 1. Evolution of FM [8].

\begin{tabular}{|c|c|c|c|}
\hline Period & Generation & Activity & Level \\
\hline $1970 \mathrm{~s}$ & $1^{\text {st }}$ & Managed services, outsourcing, total facilities management, CAFM & Operational \\
\hline $1980 \mathrm{~s}$ & $2^{\text {nd }}$ & Quality management, management agency, benchmarking, FM process, FMIS & Tactical \\
\hline $1990 \mathrm{~s}$ & $3^{\text {rd }}$ & $\begin{array}{l}\text { Partnering, re-engineering processes, knowledge management, product innovation, } \\
\text { sustainable facilities management }\end{array}$ & Strategic \\
\hline $2000 \mathrm{~s}$ & $4^{\text {th }}$ & $\begin{array}{l}\text { Business processes, open innovation, usability, service excellence transformational } \\
\text { outsourcing }\end{array}$ & Transformational \\
\hline
\end{tabular}

sustainable healthcare waste management in Malaysia. The paper provides an outlook on the state of sustainable facilities management knowledge and practice as well as the current state of FM practice in Malaysia. The paper also elevates the importance of FM performance management in SFM context taking into account the peculiar position of the facilities management.

\section{The strategic role of facilities management}

It has been agreed that FM encompasses many things, often seen as a conglomeration of several related expertise into one business support function. Presently, FM is seen as the fastest emerging and most powerful sectors in many industries having gained recognition from the 1970s when outsourcing services became popular in radical costcutting initiatives $[9,10]$. Before seen in the operational sense of cleaning, care-taking, repairs and maintenance, FM now covers "real estate management, financial management, change management, human resources management, health and safety, contract management, in additional to building and engineering services maintenance, domestic services and utilities supplies" [11] p. 75. A chronology of how FM has transformed is provided by [8] [see Table 1]. According to Barrett [1995] in [12] facilities management is "a strategically integrated approach to maintaining, improving and adapting the buildings and supporting services of an organisation in order to create an environment that strongly supports the primary objectives of that organisation", p. 3. This position has long promoted the need for FM to be strategically oriented [12]. Tucker [13], note that, FM in contemporary terms is seen as the "integration and alignment of the noncore services, including those relating to premises, required to operate and maintain a business to fully support the core objectives of the organisation". This definition resonates with the definition provided by the British Institution of Facilities Management [BIFM], the leading FM body in the United Kingdom and one of the largest in the world, "the integration of processes within an organization to maintain and develop the agreed services which support and improve the effectiveness of its primary objectives" [14]. On the other hand, the International Facility Management Association [IFMA], regarded as the largest FM organization in the world, defines FM as "a profession that encompasses multiple disciplines to ensure the functionality of the built environment by integrating people, place, process and technology" [15]. According to BIFM [14], FM “encompasses multi-disciplinary activities within the built environment and the management of their impact upon people and the workplace."

Pitt and Tucker [16] suggest that the purpose of FM is integrating noncore services to adequately support the core functions and objectives of an organization. To achieve this function, Kincaid [17] observes effective FM need to recognize three key characteristics:

- FM as a support role or service to an organization.

- Strategic, tactical, and operational activities must be integrated and linked to primary activities to create value.

- Adequate knowledge of FM among facilities managers.

Especially for large organizations, facilities management has become a vital function, providing services such as energy management, pest control, recycling, health and safety, hygiene, waste management [18]. The true importance of FM is in linking all services under its remit to organizational core objectives and creating value. FM nowadays is seen as the key link between organization or business support services to corebusiness, a vital service sector, charged with providing cost-efficient support services in a highly competitive and continually-changing business environment [10]. According to Barrett \& Baldry [19], FM offers a holistic and evolutionary approach in realizing organizational optimization and total business solutions as regards other business tools available to business outlets and organization. Thus, FM also has to operate at the same strategic level of aligning business and organizational visions, missions and objectives with its non-core business activities. Nutt [20] note that the primary role of FM is resource management at both strategic and operational levels of business support. FM today is seen as providing services at 3 levels of business support [strategic, tactical and operational levels]. According to Kamaruzzaman \& Zawawi [11], FM is a balance between these three levels.

\subsection{State of FM in Malaysia}

The facilities management profession, even around the world is still very new dating back to just over three decades ago. However, while developed nations such as the UK, US, Japan, Singapore, Australia, etc, have 
managed to establish a much robust FM sector, the case with Malaysia is starkly different. A study by Moore \& Finch [21] showed mixed signs about FM development in Malaysia with lack of understanding and progress as key aggravating factors. Tracing FM development in Malaysia goes back to the 1990 s, precisely 1996 when the government privatized non-clinical support services in public hospitals to FM companies in the biggest contract involving FM services provisions at the time [11]. In 2001, lack of a good maintenance culture prompted the then Deputy Prime Minister to lament that: "Unless Malaysians change their mentality to become more aware of the need to provide good services and improve the upkeep of buildings, we will forever be a Third World country with First World infrastructure" [11, 21]. Since then, Kamaruzzaman \& Zawawi [11], note that immense emphasis and focus have been channeled through developing FM in Malaysia especially in the public sector. The result of this could be seen also in the academic arena where a good number of prestigious Malaysian higher institutions are actively developing programs and curriculums to develop FM knowledge base in Malaysia. However, Myeda \& Pitt [9] note that there is still a passive reception about FM services in Malaysia. Key to note is the need for a shift in FM understanding in the Malaysian FM sector to reflect FM's strategic relevance, which is being championed as the core of FM practice around the world. While FM practice might have a promising future in Malaysia, Myeda \& Pitt [9] found that the practice is still immature with 63 percent of FM practice still operational, noting that traditional management, lack of FM guidelines, standards and understanding were among the factors hampering the development of the FM industry in Malaysia. The study also found that 60 percent of the surveyed FM practitioners did not implement a performance measurement system, a crucial element for assessing the performance of FM strategies.

\section{The concept of sustainable facilities management [SFM]}

The wide acknowledgement of the challenges of climate change and the effects built infrastructure have on the environment have become a great source of pressure on organizations to buy into the sustainability agenda. Larger companies, especially, are more pressured to define and show their moral positions in dealings with others and the environment [22] in an attempt to promote more inclusive and sustainable business practices. The Global Alliance for Building Sustainably [GABS] charter established in 2002 can be seen as a direct acknowledgement of the effect the built environment has on the global environment [23]. According to [5], it is fundamental to recognize sustainable FM practice as a key component to enhancing organizational competiveness. The recognition of facilities management embracing sustainable practice could be found in a 2007 IFMA report "Exploring the Current Trends and Future Outlook for Facility Management Professionals", which identified sustainability as one of the key issues facing FM professionals in this present day. According to the report, rapid development, especially in
Asia, largely accounts for environmental resource depletion, pushing for FM professionals to develop competencies in areas of sustainable development and practices [24]. The report emphasized the need for facilities managers to retain the ability to make a "business case for sustainability" through identifying and developing initiatives to reduce energy consumption, reduce waste, understand the nature of high-performance buildings as well as becoming conversant with high-performance building ratings tools, and to closely work with end users to maximize these initiatives. Similarly, [25] identified integrating all sustainability considerations, linking strategic level with operational level, incorporating FM knowledge and experience into design, disseminating sustainable knowledge and educating people, encouraging sustainability through innovation as crucial roles facilities managers could play in sustainable FM practice. The general idea of sustainable facilities management [SFM] is to incorporate sustainability practices into the operations and implementation of facilities management functions. Sustainable facilities management integrates FM and sustainability [25]. According to Tucker [13], sustainable FM is all about "being able to manage, implement and deliver an organisation's non-core business services that contribute to the improvement of the economic, social and physical environment, and, in turn, to the greater environmental sustainability on an organisation's core business objectives" $p$ 242. The potential of FM contributing to achieving sustainability goals within organizations have been acknowledged and investigated $[2,7,23,26]$. FM has been firmly established now as an integrated function that operates, manages, and improves buildings and infrastructure of organizations in order to create an environment that enables core business to thrive [27]. Added to this is the unique position of FM as a business support pillar. It suffices to say therefore, that, the concept of sustainable FM is best described in terms of an organization's economic profitability, environmental responsibility and social awareness $[13,28]$.

\subsection{Drivers for sustainable facilities management}

There seems to be a wide recognition of the benefits and importance of incorporating sustainability into FM practice $[2,3,13,22,23,25,26,28-30]$, however, studies and literature focusing on the drivers of SFM are very few $[2,25,26]$.

Elmualin et al. [2] conducted a study to identify policy and drivers for SFM practice and found that legislation, corporate image, and organization ethos were the chief drivers for SFM practice. This view has been shared by Meng [25], who identified market competition pushing organizations to maintain a corporate image to stay ahead of the competition, and legislation as the key drivers to SFM, both studies based on developed market scenario, the UK [2] and the UK and Ireland [25]. Especially for large organizations, there is pressure from legislation, fierce market competition and constantly changing business environments warranting the need to seek competitive edge. Interestingly, pressure from stakeholders, employees and lifecycle cost reduction were 
regarded as the least of the drivers to SFM practice. One could argue that organizations seem to be driven by factors of external importance than they are by factors of internal importance. In contrast, in a developing nation's scenario, Ikediashi et al. [26], while identifying corporate image as the major key driver to SFM, identified job creation for local communities, waste reduction and enhancing relationships with stakeholders as the main drivers to SFM. Pressure from senior management, pressure from clients, reduction of deforestation and government regulation were identified as the least driving factors of SFM. These observations show the predominance of environmental sustainability, with elements of social sustainability while none of the

Table 2. Drivers for sustainable facilities management.

\begin{tabular}{|c|c|c|c|}
\hline & \multicolumn{3}{|c|}{ Drivers } \\
\hline $\begin{array}{l}\text { Category/ } \\
\text { Reference }\end{array}$ & [2] & {$[26]$} & [25] \\
\hline Environmental & & $\begin{array}{l}\text { Reduction in energy consumption } \\
\text { Waste reduction } \\
\text { Increase productivity } \\
\text { Elimination of oil and air pollution } \\
\text { Sustainable urbanization } \\
\text { Reduction of deforestation } \\
\text { Reduction of carbon dioxide emissions }\end{array}$ & \\
\hline Social & $\begin{array}{l}\text { Legislation } \\
\text { Corporate image } \\
\text { Organization ethos } \\
\text { Service management/Director's } \\
\text { leadership } \\
\text { Pressure from clients } \\
\text { Pressure from employees } \\
\text { Pressure from stakeholders }\end{array}$ & $\begin{array}{l}\text { Enhance relation with stakeholders } \\
\text { Job creation for local communities } \\
\text { Government regulation } \\
\text { Corporate image } \\
\text { Pressure from clients } \\
\text { Pressure from senior management }\end{array}$ & $\begin{array}{l}\text { Market competition } \\
\text { [corporate image] } \\
\text { Government legislation }\end{array}$ \\
\hline Economic & Lifecycle cost reduction & $\begin{array}{l}\text { Financial gain } \\
\text { Investment drive } \\
\text { Life cycle cost reduction } \\
\text { Profitability } \\
\text { To remain competitive } \\
\text { Market expansion }\end{array}$ & \\
\hline
\end{tabular}

major key drivers were of economic derivation. There have been proponents of sustainability being viewed from the perspective of an overarching whole where the environmental aspect embraces both the social and economic aspects [31] with the position that efforts addressing environmental sustainability would inevitably trickle down benefits of social and then economic nature. A categorization of sustainable FM drivers, derived from [26] is shown in Table 2.

\subsection{Sustainable facilities management aspects}

It can be argued that the concept of sustainable FM does not create totally new functions for facilities managers, but rather requires facilities managers to incorporate aspects of environmental, economic and social sustainability into existing FM functions. The following have been identified as aspects facilities managers could harness to deliver sustainable FM functions within an organization [13, 22]: energy management, water management, waste management, air and environmental quality management, reducing vehicle use, sustainable maintenance, sustainable purchasing, environmental or ecological management, and social sustainability. While it is practically difficult to get all of these aspects to yield predominant results within an organization at once, adopting a few to front run the organization's sustainability goals is key to achieving sustainable FM functions with the organization. For instance, Tucker [13] opined that sustainable policies and operational practices could fail if there is no appropriate environmental management systems [EMS] in place to monitor, review, check and improve such policies and practices, noting further that, the most effective tool for enhancing the ability of organizations to successfully implement sustainable FM is through implementation of EMS with the FM function. At the operational level, Tucker [13] identified the following as considerations for sustainable FM delivery:

- Sustainable cleaning and reducing water usage automated toilets, waterless urinals, low flow taps/spray taps, use of low VOC and non-toxic cleaning compounds, etc.

- Sustainable catering - use of locally grown food, reusable, compostable or recyclable dinnerware, intelligent cooking, composting, etc.

- Sustainable travel - implementation of car sharing within organization's fleet, provision of bicycles, electric vehicles, etc.

- Waste disposal and recycling-provision of central printing zones, bin color coding, paper 
shredding on-site, digital media [CDs and DVDs], dry cell batteries recycling, etc.

- Space management - hot-desking, flexible workplace, etc.

- Reducing energy from mechanical and electrical [M\&E] services - use of energy rated appliances, implementing shut-down periods and zones for say lifts, recovery of energy, eco lifts, etc.

A study by Elmualim et al. [2] identified waste management and recycling, energy management, and carbon footprint as the main FM services prioritized in organizations sustainability policies. Health and safety, and sustainable travel followed while staff productivity, biodiversity, building disposal were the least sustainability issues. In complete contrast, the study found that the practical implementation did not tally with the priorities set by the sustainability policy. While the sustainability policy prioritized waste management and recycling, energy management, and carbon footprint in that order, energy management, waste management and recycling, and health and safety in that order on the other hand were the FM services FM managers concentrated on delivering. This misplacement could be traced to the major driver of sustainable FM practice, which is legislation. Pressure to comply with strict legislation set by the government suggests, organizations sustainability priorities could be overridden by operationalizing certain FM services over others even where the sustainability policy states otherwise.

\subsection{Formulating a sustainable facilities management strategy}

Hodges [6] noted that developing a sustainable FM strategy is not different from any strategic planning or goal-setting process. The traditional approach to strategic planning such as carrying out a SWOT analysis, benchmarking, therefore applies. This must not be in isolation of the organization's sustainability policy. Despite limited research regarding the drivers of sustainability policies in organizations, legislation and corporate image have been identified as the main drivers of organization's sustainability policies [2, 25, 26]. Therefore, the sustainability strategy must be formulated around the organization's overarching economic, social, and environmental goals [6] to deliver a rounded service [3]. This is to say that, an organization's overall sustainability policy forms the basis for formulating a sustainable FM strategy. With the nature of his functions, the facilities manager usually is the key professional in leading the sustainability strategy. This is as a result of the facilities manager's ability to bridge the gap between all the critical phases of a building's life cycle [6]. Hodges [6] further identified the following key steps to developing a sustainability strategy:

- Thoroughly understand the organization's philosophy and strategy regarding handling finances: identifying the organization's core values and resources and defining the fit of the sustainability strategy.
- Facilitate the strategic planning process for the organization: initiating the sustainability strategy and selling it to the top management.

- Develop a strategic plan for sustainability: mapping out a strategic plan for sustainability that defines actionable processes for the sustainability strategy.

- Implement the strategy: actual and operational level execution of the strategy.

- Become the advocate of the strategy: championing and leading the strategy implementation.

On the other hand, the BIFM proposes ten [10] steps to implementing a sustainability policy [13]:

- Identify stakeholders and map their expectations

- Confirm organizational policy mission

- Agree a sustainability policy mission

- Get a high-level sponsor

- Agree policy boundaries

- Provide adequate resources

- Set SMART targets

- Engage staff

- Communicate success

- Review and feedback

\section{Performance measurement for sustainable facilities management implementation}

Traditionally, performance measurement is viewed as having three main purposes: to ensure the achievement of goals and objectives; to evaluate, control and improve procedures and processes; and to compare and assess the performance of different organizations, teams and individuals [32]. Recently, performance measurement has become a very popular topic discussed and researched in many fields [33]. Amaratunga \& Baldry [34] describe performance measurement as a "process of assessing progress towards achieving pre-determined goals, including information on the efficiency by which resources are transformed into goods and services, the quality of these outputs and outcomes, and the effectiveness of organisational objectives". The basic foundations of performance measurement as noted by Sapri \& Pitt [32] are quantifications of elements and processes, which have an impact on organizational objectives, management control and evaluation. Parker [35] note that, organizations measure performance for the following reasons:

- Identify success

- Identify whether they are meeting customer requirements: unless they measure, how do they know that they are providing the services/products that their customers require?

- Help them understand their processes: to confirm what they know or reveal what they do not know

- Identify where problems bottlenecks, waste, etc., exist and where improvements are necessary

- Ensure decisions are based on fact, not on supposition, emotion or faith or intuition 
- Show if improvements planned, actually happened

It is generally contended that, to achieve organizational effectiveness, performance measurement systems have to be developed and implemented. Over the years, performance measurement frameworks relying on financial indicators have been heavily criticized for shortcomings such as being historically focused, lacking strategic focus, inward-looking, failing to incorporate intangible factors, encouraging short-termism, failing to provide information on need of customers [35]. The downfall of exclusively financial focused frameworks lie in their failure to provide the information necessary for managers to undertake forward planning, an invaluable need in a constantly changing business environment [36]. Many authors and researchers have created a number of performance measurement frameworks that attempt to incorporate both tangible and intangible measures, most notably, the Balanced Scorecard [BSC] by Kaplan and Norton in 1992. According to Kaplan \& Norton [37], the Balanced Scorecard enable organizations to "track financial results while simultaneously monitoring progress in building the capabilities and acquiring the intangible assets they would need to future growth" p. 150 .

It is argued that organizations implementing balanced performance measures have performed better than organizations which do not [38]. The ability of an organization to mobilize and exploit its intangible or invisible assets has become far more decisive than investing and managing physical, tangible assets [37].

The importance of measuring FM performance is noted by [39], as one of the "three essential issues for the effective implementation of a facilities strategy". Despite the FM function being positioned as one of strategic relevance to organizations [40], the FM function is one most prone to budget cuts. This position has been made possible by a dual view of facilities. To some organizations, facilities are a cost center, draining organizational resources, as such a business expense to be minimized [41]. It could be contended that view of FM as a non-value adding function, seeing that support services could account for up to 30 to 40 per cent of organizations' operating budgets, second only to payroll [42] created the second perspective of FM which is that of seeing facilities as an integral and a strategic support service to organizations $[20,27,41]$. The former view therefore justifies the widespread pressure for the added-value FM function [42] that could only be evidenced by value-adding performance output.

Major facilities performance measurement practices include benchmarking, a balanced scorecard approach, post occupancy evaluation, and measurement through metrics of key performance indicators [KPIs] [43]. Facilities performance measurement techniques such as the Post Occupancy Evaluation, the BIFM measurement protocol, Hierarchical system of performance indicators, input versus output based performance measurement focus primarily on either technical or financial aspects of facilities performance [44], and do not indicate the contribution made to the organization's strategic results [45]. Amaratunga and Baldry [34] suggested the application of the Balanced Scorecard approach to facilities management performance measurement. The application of the Balanced Scorecard as an appropriate facilities performance measurement model is in an attempt to overcome the deficiencies of traditional performance management models which have been heavily criticized for relying only on financial indicators. The challenges of the current business environment are numerous, and completely different from the era of the performance measurement based on financial indicators alone. In the light of value-driven benefits for the organization, Varcoe [46] noted that old-style measures such as financial based indicators for business performance measurement have gone past their "sale-by date" as they provide no solution to addressing the overall business value obtained from the expenditure. The Procurement Executives' Association [47] notes the following challenges of the business environment in the new millennium:

- technology advances beyond our wildest imaginings;

- resources becoming more scarce;

- higher efficiency of operations demanded by customers;

- discretion rather than rules dominating; and

- outcomes/results-oriented management flourishing

Performance measurement systems therefore have to be flexible and holistic to cope with the constant evolution of organizations [48]. Amaratunga \& Baldry [49] contend that, measurement is not an end in itself, but a tool for more effective management. It is argued that organizations need to transition from just measuring performance to actually managing it in order to maximize the use of its performance measurement outcomes and create strategic value [16, 49]. To successfully transition from performance measurement to performance management Amaratunga \& Baldry [49] suggests that the right organizational structure for performance measurement, and the ability to use performance measurements outcomes to effect change in the organization must be in place. Performance management has been defined by the Procurement Executives' Association as "the use of performance measurement information to effect positive change in organizational culture, systems and processes, by helping to set agreed-upon performance goals, allocating and prioritizing resources, informing managers to either confirm or change current policy or program directions to meet those goals, and sharing results of performance in pursuing those goals" [47], p. 5. Amaratunga \& Baldry [49] noted the following attributes of a performance management system for FM organizations:

- leadership involvement in designing and deploying effective performance measurement and management systems;

- effective and open communication between employees, stakeholders, and customers in order to share assessment results and any new initiatives to improve performance;

- accountability of results which are clearly assigned and well understood; 
- compensation, rewards and recognition that are linked to performance measures;

- $\quad$ targets that are linked to appraisals; and

- a performance measurement system that is positive.

Effective performance management requires the consideration of strategic goals and incorporating them into the performance management system [49].

The integration of sustainability aspects into the FM function requires performance measurement metrics that reflect the sustainability objectives set out by the sustainable facilities management strategy. Eagan \& Joeres [50] identified the International Standards Organization [ISO-14031), British Standards [BS-7750], and the European Union's Eco-management and Auditing Schemes [EMAS] as among the organizations developing guidelines to evaluate environmental performance of facilities. They noted the growing significance of deriving performance measurement metrics to measure the sustainability performance of facilities, contending that current performance measurement approaches included indicators relating to processes, results, and customer satisfaction, barely focus on holistically addressing focus on sustainable development related goals. Epstein \& Wisner [51] suggested an environmental and social perspective be incorporated into the Balanced Scorecard approach, noting the success story of two organizations
[Bristol-Myers Squibb and Severn Trent] that successfully used a Balanced Scorecard approach to measure the sustainability performance of buildings.

\subsection{Linking performance to organizational core business strategy and objectives}

The contribution, or lack of it, that FM makes to the core business of an organization and the degree it accomplishes this support function is the basis for assessing FM performance [42]. Amaratunga \& Baldry [49] contend that, performance management systems provide a means for FM organizations to continually test their FM strategies, providing real-time information regarding the status of their strategies, whether they are working or not, and most importantly, why, if they are not.

Amaratunga [33] contend that, for facilities performance measures to be effective, the facilities strategy has to be aligned with the core business/organizational strategy. Cable \& Davis [52] add that facilities must be assessed for their alignment with an organization's objectives in order to recognize how well a facility helps the organization meet its goals and fulfill its mission. It becomes necessary to derive facilities performance measures that reflect the business performance position of the organization. Amaratunga et al. [42] note that the KPIs of the future may have

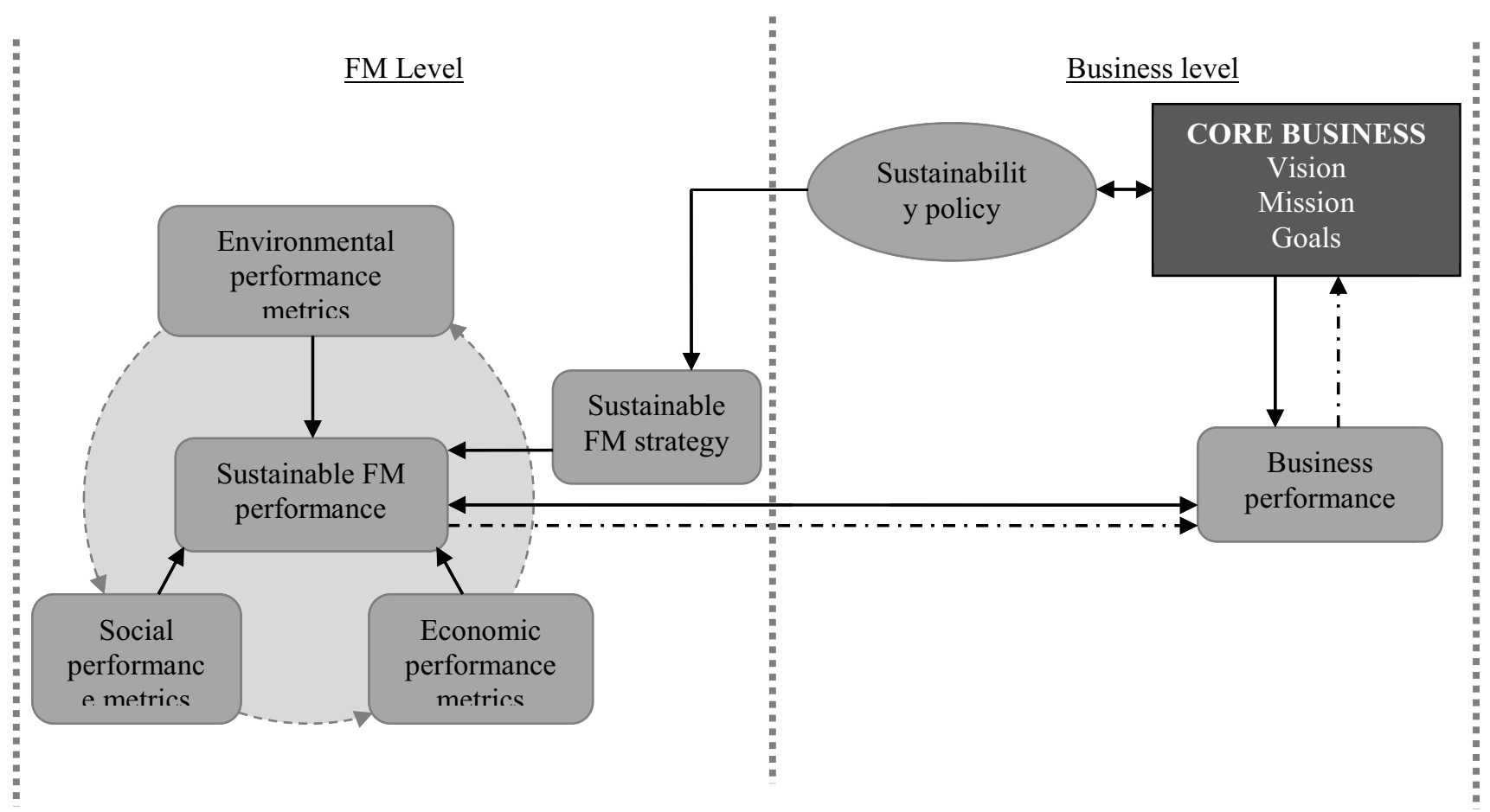

Figure 1: Linking SFM performance with organizational core business conceptual framework

to be directed more toward business outcomes, and could converge with core business performance indicators such as agility, flexibility, business continuity and transition management. In the view of this, Hinks [53] describe how necessary it is for facilities managers to begin speaking the business language to become more recognized at the business level. In a study conducted by the author, FM practitioners rated business performance measures differently from facilities performance measures. The author argued that, why the practitioners clearly recognized the need to differentiate facilities performance measures from business performance measures, there is need to link these two. This argument suggest that the wide disparity in rating between facilities performance 
measures and business performance measures create polarized priorities, making it difficult for the value added by the FM function to the organization be fully recognized. In Figure 1, a conceptual framework for linking sustainable FM performance to core business is proposed.

\section{Conclusion}

Organizations are looking to demonstrate their sustainability credentials and the facilities manager is at the forefront of championing this effort. Sustainable facilities management is considered a critical aspect of achieving the sustainability goals of organizations. This paper relied on a review of literature on the subject of sustainable facilities management and facilities performance in the context of adding value to the organization's overall sustainability agenda and goals. Several aspects the facilities manager must harness to achieve these goals have been identified to include energy management, water management, waste management, air and environmental quality management, sustainable travel, sustainable maintenance, sustainable purchasing, environmental or ecological management, and social sustainability. The challenge for the facilities manager is to bring these aspects to support the sustainability policy of the organization. The disharmony between organizations' sustainability priority areas and the responsibilities for facilities managers to execute them where the sustainability policy of organizations prioritize one FM service and the facilities managers' responsibilities prioritize another could be argued as a clear disparity between knowledge and practice. The increasing recognition of the need for the strategic FM function, and how facilities managers are best positioned to drive organizations' sustainability agendas remains a source of pressure for facilities managers to prove the strategic value of FM to their organizations. In Malaysian context, this recognition is barely evident as findings show FM practice is still immature and predominantly operational. The argument that facilities performance needs to link with business performance led the authors to propose a conceptual framework that recognizes the need for a closer communication between facilities performance management systems and business performance management systems. For the facilities management function as a whole to express its value to the organization, it needs to measure what it contributes to the core business of the organization. The authors recognize the need for further research to validate and empirically demonstrate a framework for sustainable facilities management performance for the value-added FM function.

\section{References}

1. Wood, B., The role of existing buildings in the sustainability agenda. Facilities, 2006. 24(1-2): p. 61-67.

2. Elmualim, A., R. Valle, and W. Kwawu, Discerning policy and drivers for sustainable facilities management practice. International
Journal of Sustainable Built Environment, 2012. 1: p. 16-25.

3. Elmualim, A., et al., Barriers and commitment of facilities management profession to the sustainability agenda. Building and Environment, 2010. 45(1): p. 58-64.

4. Organization for Economic Cooperation and Development (OECD), Environmentally sustainable buildings: challenges and policies, 2003, OECD: Paris.

5. Baharum, M.R. and M. Pitt, Determining a conceptual framework for green FM intellectual capital. Journal of Facilities Management, 2009. 7(4): p. 267-282.

6. Hodges, C.P., A facility manager's approach to sustainability. Journal of Facilities Management, 2005. 3(4): p. 312-324.

7. Price, S., M. Pitt, and M. Tucker, Implications of a sustainability policy for facilities management organisations. Facilities, 2011. 29(9/10): p. 391410.

8. Alexander, K. European Facilities Management: the next generation. 2009, Nardeen: EuroFM.

9. Myeda, N.E. and M. Pitt, Facilities management in Malaysia: Understanding the development and practice. Facilities, 2014, 32(9/10).

10. Nazali Mohd Noor, M. and M. Pitt, A critical review on innovation in facilities management service delivery. Facilities, 2009, 27(5/6): p. 211228.

11. Kamaruzzaman, S.N. and E.M.A. Zawawi, Development of facilities management in Malaysia. Journal of Facilities Management, 2010. 8(1): p. 75-81.

12. Alexander, K., et al., eds. Facilities Management: Innovation and Performance. 2004, Oxon: Spon Press.

13. Tucker, M., Sustainable facilities management, in Total Sustainability in the Built Environment, A. Cotgrave and M. Riley, Editors. 2013, Basingstoke: Palgrave Macmillan.

14. British Institute of Facilities Management (BIFM), Facilities Management Introduction. 2014, Available from: http://www.bifm.org.uk/bifm/about/facilities.

15. International Facility Management Association (IFMA), What is Facility Management. 2013, Available from: http://www.ifma.org/about/what-is-facilitymanagement.

16. Pitt, M. and M. Tucker, Performance measurement in facilities management: driving innovation? Property Management, 2008. 26(4): p. 241-254.

17. Kincaid, D., Integrated Facility Management. Facilities, 1994. 12(8): p. 20-23.

18. Baharum, M.R., Recycling initiatives in the UK shopping centres, factors critical to success 2011, Unpublished $\mathrm{PhD}$ thesis, Liverpool John Moores University. 
19. Barrett, P. and D. Baldry, Facilities Management: Towards Best Practice. 2nd ed. 2003, Oxford: Blackwell.

20. Nutt, B., Four competing futures for facility management. Facilities, 2000. 18(3/4): p. 124132.

21. Moore, M. and E. Finch, Facilities management in South East Asia. Facilities, 2004. 22(9/10): p. 259-270.

22. Appleby, P., Sustainable retrofit and facilities management. 2013: Abingdon: Routledge.

23. Shah, S.S., Sustainable practice for the facilities manager. [electronic resource]. 2007: Oxford: Blackwell.

24. International Facility Management Association (IFMA), Exploring the current trends and future outlook for facility management professionals, 2007, IFMA Report, Facility Management Forecast, 2007.

25. Meng, X., The role of facilities managers in sustainable practice in the UK and Ireland. Smart and Sustainable Built Environment, 2014. 3(1): p. 23-34.

26. Ikediashi, D.I., S.O. Ogunlana, and A.O. Ujene, An investigation on policy direction and drivers for sustainable facilities management practice in Nigeria. Journal of Facilities Management, 2014. 12(3): p. 303-322.

27. Nutt, B., Infrastructure resources: forging alignments between supply and demand. Facilities, 2004. 22(13/14): p. 335-343.

28. Pitt, M., et al., Towards sustainable construction: promotion and best practices. Construction Innovation, 2009. 9(2): p. 201.

29. Elmualim, A., et al., The Practice of Sustainable Facilities Management: Design Sentiments and the Knowledge Chasm. Architectural Engineering \& Design Management, 2009. 5(1/2): p. 91-102.

30. Wetering, J.v.d. and P. Wyatt, Office sustainability: occupier perceptions and implementation of policy. Journal of European Real Estate Research, 2011. 4(1): p. 29-47.

31. SANZ, S.A.N.Z.I., Strong sustainability for New Zealand: principles and scenarios 2009, New Zealand: SANZ.

32. Sapri, M. and M. Pitt. Performance measurement in facilities management; state of knowledge. in 21st Annual ARCOM Conference, 7-9 September 2005, SOAS. 2005. University of London: Association of Researchers in Construction Management.

33. Amaratunga, R. D. G., Theory building in facilities mangement performance: application of some core performance measurement and management principles 2001, Unpublished PhD thesis, University of Salford.

34. Amaratunga, D. and D. Baldry, A conceptual framework to measure facilities management performance. Property Management, 2003. 21(2): p. 171-189.
35. Parker, C., Performance measurement. Work study, 2000. 49(2): p. 63-66.

36. Neely, A., The performance measurement revolution: why now and what next? International journal of operations \& production management, 1999. 19(2): p. 205-228.

37. Kaplan, R.S. and D.P. Norton, Using the Balanced Scorecard as a Strategic Management System. Harvard Business Review, 2007. 85(7/8): p. $150-161$.

38. Kennerley, M. and A. Neely, Performance measurement frameworks: a review, in Business performance measurement: Theory and practice, A. Neely, Editor. 2002, Cambridge: Cambridge University Press, p. 145-155.

39. Alexander, K., ed. Facilities Management: Theory and Practice. 1996, Oxon: Taylor \& Francis.

40. Alexander, K., A strategy for facilities management. Facilities, 2003. 21(11/12): p. 269274.

41. Madritsch, T. and M. Ebinger, Performance Measurement In Facility Management The Environment Management Maturity Model Bem3. Research Journal of Economics, Business and ICT, 2011. 2.

42. Amaratunga, D., D. Baldry, and M. Sarshar, Assessment of facilities management performance - what next? Facilities, 2000. 18(1/2): p. 66-75.

43. Lavy, S., J.A. Garcia, and M.K. Dixit, Establishment of KPIs for facility performance measurement: review of literature. Facilities, 2010. 28(9/10): p. 440-464.

44. Amaratunga, D. and D. Baldry Performance measurement in facilities management organisations: transition from measurement to management. 2002, Available from: http://usir.salford.ac.uk/9903/1/performance_me asurement.pdf

45. Brackertz, N., Relating physical and service performance in local government community facilities. Facilities, 2006. 24(7/8): p. 280-291.

46. Varcoe, B.J., Facilities performance measurement. Facilities, 1996. 14(10/11): p. 4651.

47. Procurement Executives Association (PEA), Guide to a balanced scorecard performance management methodology: moving from performance measurement to performance management, 1999, Available from: http://web.cjcu.edu.tw/ lcc/Courses/BalancedSc orecardPerfAndMeth\%20Tutorial.pdf.

48. Neely, A., M. Gregory, and K. Platts, Performance measurement system design: a literature review and research agenda. International journal of operations \& production management, 2005. 25(12): p. 1228-1263.

49. Amaratunga, D. and D. Baldry, Moving from performance measurement to performance management. Facilities, 2002a. 20(5/6): p. 217223. 
50. Eagan, P.D. and E. Joeres, Development of a facility-based environmental performance indicator related to sustainable development. Journal of Cleaner Production, 1997. 5(4): p. 269278.

51. Epstein, M.J. and P.S. Wisner, Using a Balanced Scorecard to Implement Sustainability. Environmental Quality Management, 2001. 11(2): p. 1-10.

52. Cable, J.H. and J.S. Davis, Key Performance Indicators for Federal Facilities Portfolios, Federal Facilities Council Technical Report 147, 2004: National Academies Press Washington, DC.

53. Hinks, J., Business-related performance measures for facilities management, in Facilities Management: Innovation and Performance, $\mathrm{K}$. Alexander, et al., Editors. 2004, New York: SPON Press, p. 97-107. 